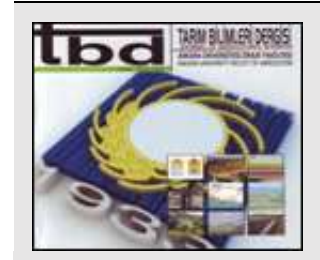

Tarım Bilimleri Dergisi Tar. Bil. Der.

Dergi web sayfasi: www.agri.ankara.edu.tr/dergi
Journal of Agricultural Sciences

Journal homepage:

www.agri.ankara.edu.tr/journal

\title{
Modeling and Design a Special Type of Passive Solar Greenhouse in Cold Climate by TRNSYS
}

\author{
Saleh MOHAMMADI ${ }^{a}$, Amir Hosein Afkari SAYYAH ${ }^{a}$, Ali Mohammad NIKBAKHT ${ }^{\text {, Esmail KHALIFE }}$ \\ ${ }^{a}$ Department of Mechanic of Biosystems Engineering, University of Mohaghegh Ardabili, Ardabil, IRAN \\ ${ }^{b}$ Department of Mechanic of Biosystems Engineering, University of Urmia, Urmia, IRAN

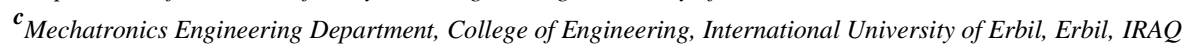

\author{
ARTICLE INFO \\ Research Article \\ Corresponding Author: Amir Hosein Afkari SAYYAH, E-mail: acafkari@gmail.com, Tel: +(98) 9144529813 \\ Received: 25 December 2018, Received in Revised Form: 20 August 2019, Accepted: 31 August 2019
}

\section{AUTHORS ORCID ID:}

(Saleh MOHAMMADI: 0000-0001-7142-0625 ), (Amir Hosein Afkari SAYYAH: 0000-0003-0534-688X ), (Ali Mohammad NIKBAKHT: 0000-0003-4431-5402 ), (Esmail KHALIFE: 0000-0002-1690-1714)

\section{ABSTRACT}

To improve the thermal performance, storage and saving heat solar energy of conventional greenhouse, a passive solar greenhouse was built which its north wall was made of soil. The bottom part of the north, south, west and east walls were sloping and constructed below ground surface. The indoor air temperature was measured during January and February. To optimize the size of greenhouse in cold climate condition a TRNSYS model was created and validated using experimental data. According to the results obtained, Total Incident Solar Radiation (TISR) in the north wall was $484 \mathrm{MJ}$ during January and February and there was the possibility of cultivation in it. More specifically, the variation of TISR during 60 days varied from 190 to $3811 \mathrm{~kJ} \mathrm{~h}^{-1} \mathrm{~m}^{-2}$. The indoor air temperature of the greenhouse varied from -4.3 to $42.4{ }^{\circ} \mathrm{C}$ while the outdoor temperature fluctuated between -13.8 to $10.6{ }^{\circ} \mathrm{C}$. In addition, the differential temperature between modeled and measured data at climate conditions of snowy, rainy, cloudy and sunny days were 2.3 , $0.2,0.2$, and $2.6^{\circ} \mathrm{C}$ during daytime and $-1.8,-2,0.3$ and $1{ }^{\circ} \mathrm{C}$ at nighttime, respectively. The obtained coefficient of determination $\left(\mathrm{R}^{2}\right)$ was $95.95 \%$ for measured and modeled data.

Keywords: Passive solar greenhouse; Renewable energy; TRNSYS; Solar radiation

\section{Introduction}

By increasing fossil fuel price and its effect on greenhouse gases (GHG), researchers are attempting to develop energy saving technologies (Erdem et al 2016). In cold climate, reducing energy consumption for greenhouse heating is an important parameter for greenhouse existence (Mathala et al 2002). A lot of research efforts have been made to improve energy consuming of active and passive greenhouse types (Alkilani et al 2011). There are several methods for this aim such as thermal insulation, solar energy, earth to air heat exchanger, geothermal energy, and different heat storage system (Beshada et al 2006; Mashonjowa et al 2013; Patil et al 2013; Sethi et al 2013; Zhang et al 2015; Bin et al 2016; Jieyu et al 2017; Wei et al 2017). Each of these methods has been reported to be efficient in a specific climate condition.

For instance, Beshada et al (2006) investigated a passive solar greenhouse using thermal blanket for reducing heat loss during winter condition in southern Manitoba. The greenhouse had an insulated solid north wall to store solar energy in the daytime and afterward to release saved thermal energy in the nighttime. In addition, they used a thermal blanket which covered the glazed surface (single layer plastic) in the nighttime to minimize the heat loss. In another research, Bin et al (2016) conducted a study to assess thermal performance improvement of conventional single span 
greenhouses in different condition of half-removable back wall and fully-removable back wall. The thermal environment of the greenhouses was recorded and compared with a typical single span polyethylene hoop greenhouse. They claimed that the both two investigated greenhouse types showed that could be better alternatives to the conventional greenhouse (Bin et al 2016). Lately, Jieyu et al (2017) investigated on a solar greenhouse which was equipped with economical energy storage device for managing greenhouse stored energy. Wall storage actively managed with energy-store/retrieve funs and safety energy which is a solar collector and fully thermally isolated heat tank. In another study, a solar greenhouse was designed to use thermal storage of a water storage tank for heating. The water tank was heated using solar energy. The experimental greenhouse was $272 \mathrm{~m}^{2}$ area which was equipped with 46 $\mathrm{m}^{2}$ solar collecting plates. Their results showed that an additional $14 \mathrm{~m}^{2}$ solar collector was needed to maintain greenhouse night air temperatures above $12{ }^{\circ} \mathrm{C}$ whereas outdoor average nighttime temperature was less than $7.8{ }^{\circ} \mathrm{C}$ (Wei et al 2017).

In regard to this fact, experimental works need a lot of budget therefore simulation model is an easy way to reduce costs and as well as reducing human errors. There are a lot of simulation researches to model greenhouse structure and inside temperature managing. For instance, Zhang et al (2015) proposed developing and investigation of soil heat storage for the greenhouse and compared experimental and simulation results. Attar et al (2014) investigated solar water heating system and influencing parameters on storage system.

Amongst all different modeling software, TRNSYS (TRaNsient System Simulation) is complete and extensible simulation software for the transient simulation of multi-zone buildings like greenhouses. It is employed to validate energy concepts of systems, such as to design and simulate hot water system of building, air conditioner equipment, control strategy and renewable energy systems. TRNSYS could easily connect graphical components described by mathematical model of a system in the Simulation Studio (Vadiee \& Martin 2013; Attar et al 2014). This simulation software provides a lot of choices to find better analyzing of energy systems of agriculture building. In recent years, several studies have been done by agriculture researchers by using TRNSYS for design the greenhouse structure, energy management, and analyzing solar heating system and different energy resources. A lot of researchers have successfully evaluated feasibility of predicting and modeling greenhouse air temperature using TRNSYS to minimize the energy consumption using solar energy (Chung et al 1998; Voulgaraki \& Papadakis 2008; Vadiee \& Martin 2012; Asdrubali et al 2012; Carlini et al 2012; Chargui et al 2012; Marucci et al 2013; Mashonjowa et al 2013; Patil et al 2013; Vadiee \& Martin 2014; Attar et al 2014; Ishigami et al 2014; Zhang et al 2015).

Candy et al (2012) designed a greenhouse in remote region in Humla, Nepal and used TRNSYS for modeling the greenhouse. The result showed good agreement between measured data obtained from created greenhouse and those of modeled by TRNSYS. One year later, Patil et al (2013) assessed solar heating of a greenhouse with seasonal storage. They focused on comparing results obtained from TRNSYS and EQUEST on controlling environment temperature, thermal storage, and solar thermal heat of the greenhouse. In another study a semi-solar greenhouse was studied by Taki et al (2016). In this research, the inside environment parameters were considered which were inside air temperature below screen, inside air temperature above screen, crop temperature, inside soil temperature, cover temperature, and thermal screen temperature $\left(\mathrm{T}_{\mathrm{sc}}\right)$. In addition, they investigated dynamic heat and mass transfer model to find temperature in different points and crop evapotranspiration of the semi-solar greenhouse. Lately, Carlini et al (2012) studied on thermal behavior of greenhouse and thermal exchange rate in a greenhouse by using TRNSYS.

In present study, a passive solar greenhouse constructed $1 \mathrm{~m}$ below the surface of the ground and subsequently the greenhouse was modeled by TRNSYS. The north wall in present work was constituted by excavated soil. In this research, we are investigated on modeling indoor temperature and TISR on five different points (soil, 2, 1.5, 1, and $0.5 \mathrm{~m}$ height) on walls, roof, and floor. Validation was done using measured indoor air temperature in different days (snowy, cloudy, rainy and sunny) and their comparison with those obtained from TRNSYS model was done as well.

\section{Material and Methods}

The paper presented is in large part based on the operational characteristics of greenhouses in Tabriz; a region with the cold climate for greenhouses in northwestern of Iran. Information has been obtained from the software program TRNSYS. This design (shown in Figures 1 and 2) is intended to be built on a flat surface in a cold climate with minimum winter temperatures of more than $-13^{\circ} \mathrm{C}$. To conform this design for Tabriz, a number of changes were necessary related to mathematic basic, materials, size, heating, cooling, ventilation, and glazing. 


\subsection{Mathematical description}

Energy and mass balance equations were used in TRNSYS in order to calculate the temperature of the proposed thermal zones. The sensible energy balance for an arbitrary thermal zone (i) is defined by Equation 1:

$\dot{Q}_{\mathrm{i}}=\dot{Q}_{\text {surf } \mathrm{I}}+\dot{Q}_{\mathrm{inf}, \mathrm{I}}+\dot{Q}_{v e n t, I}+\dot{Q}_{\mathrm{gc}, \mathrm{I}}+\dot{Q}_{\mathrm{cplg}, \mathrm{i}}$

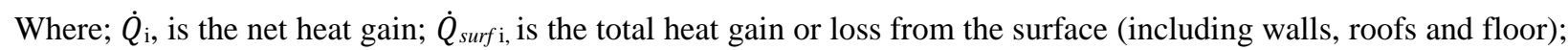
$\dot{Q}_{\text {inf i }}$, is the infiltration gains (air flow from outside only); $\dot{Q}_{v e n t, i}$, is the ventilation heat gain from the user defined source; $\dot{Q}_{g c i}$, is the internal convective heat gain by crops, people and other equipment; and $\dot{Q}_{\text {cplg i i }}$, is the convective heat gain.

$C_{p}$, is fluid specific heat $\left(\mathrm{kJ} \mathrm{kg}^{-1} \mathrm{~K}^{-1}\right) ; \dot{V}$, is rate of attic infiltration of outside air $\left(\mathrm{m}^{3} \mathrm{~h}^{-1}\right) ; \rho$, is density of outside air $\left(\mathrm{kg} \mathrm{m}^{-3}\right) ; \mathrm{T}_{\text {Zone, }}$ is zone temperature $\left({ }^{\circ} \mathrm{C}\right) ; \mathrm{T}_{\text {ventilation, }}$, is temperature of ventilation air $\left({ }^{\circ} \mathrm{C}\right)$.

$\dot{Q}_{\text {inf } \mathrm{i}=} \dot{V} \cdot \rho \cdot \mathrm{C}_{\mathrm{p}}\left(\mathrm{T}_{\text {outside, } \mathrm{i}}-\mathrm{T}_{\text {air }}\right)$

$\dot{Q}_{\text {vent } i=} \dot{V} \cdot \rho \cdot \mathrm{C}_{\mathrm{p}}\left(\mathrm{T}_{\text {ventilation, } \mathrm{i}}-\mathrm{T}_{\text {air }}\right)$

$\dot{Q}_{\mathrm{cplg}}=\dot{V} \cdot \rho \cdot \mathrm{C}_{\mathrm{p}}\left(\mathrm{T}_{\text {zone, } \mathrm{i}}-\mathrm{T}_{\text {air }}\right)$

The energy balance of the greenhouse consists of heat source and heat sinks in the greenhouse (equation5) due to different heat transfer phenomena (TRNSYS 17 Multizone Building modeling).

Heat storage $=$ Heat gains $($ Heat source $)+$ Heat losses $($ Heat sinks $)$

In present greenhouse, the walls were created by soil and the south side was covered by polyethylene film to reduce heat losses (Figure 1). The soil surface temperature is higher than the indoor air temperature during the winter nights (Wei et al 2017). This is due to the heat storage of the absorbed solar radiation by soil during the day and its thermal capacity (Joudi \& Farhan 2015). Since, solar radiation is not available during the night, heat stored in the soil bed transferred to the surface and is released indoor. In fact, on winter's days, the solar radiation absorbed by the soil surface could divided in two parts, one for heating the air in the greenhouse and other being transferred to the deeper soil (Chen \& Liu 2006).

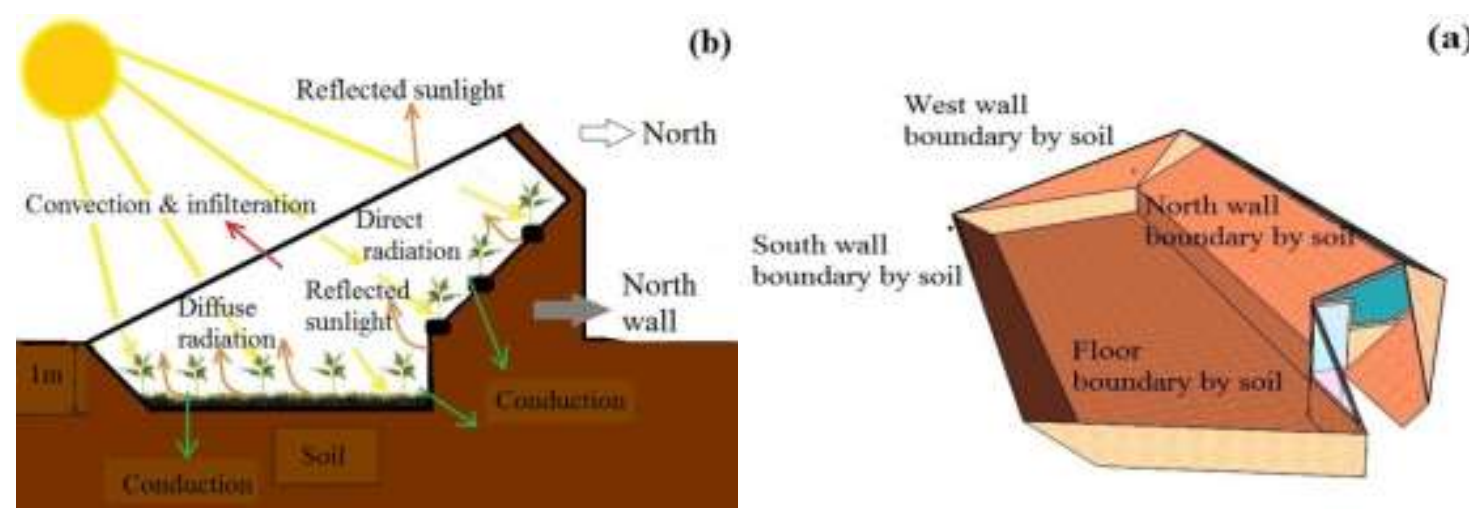

Figure 1- Schematic views as 3D (a) and 2D (b) of greenhouse parts

\subsection{Design and modeling}

Three software tools were used to construct the building models: sketch UP which is a 3-D drawing tool, TRNBUILD which is an interface to add the physical properties of the building to the geometry definition, and TRNSYS which is an 
energy systems simulation software package. To produce an accurate model the following three steps need to be taken into account. At first, a three dimensional model of the building was drown in SKETCHUP, then the 3-D model was imported to TRNBUILD to add the thermal properties of the greenhouse and create the greenhouse information file (BUI) and at last the BUI was imported to TRNSYS for simulation the model to obtain different parameters especially temperature under various air and greenhouse conditions. In this study, a dynamic simulation model was developed to find greenhouse thermal performance using the TYNSYS simulation platform (Candy et al 2012). For this aim, the greenhouse geometry was imported into TRNSYS and became the basis of a greenhouse (type 56) (Figure 2 and 3 ).

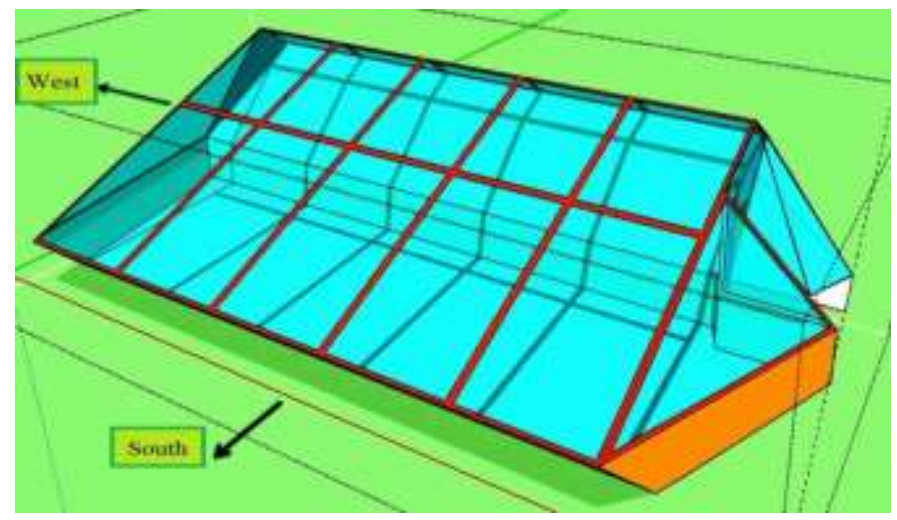

Figure 2- The sketchup of 3-D model of passive solar greenhouse

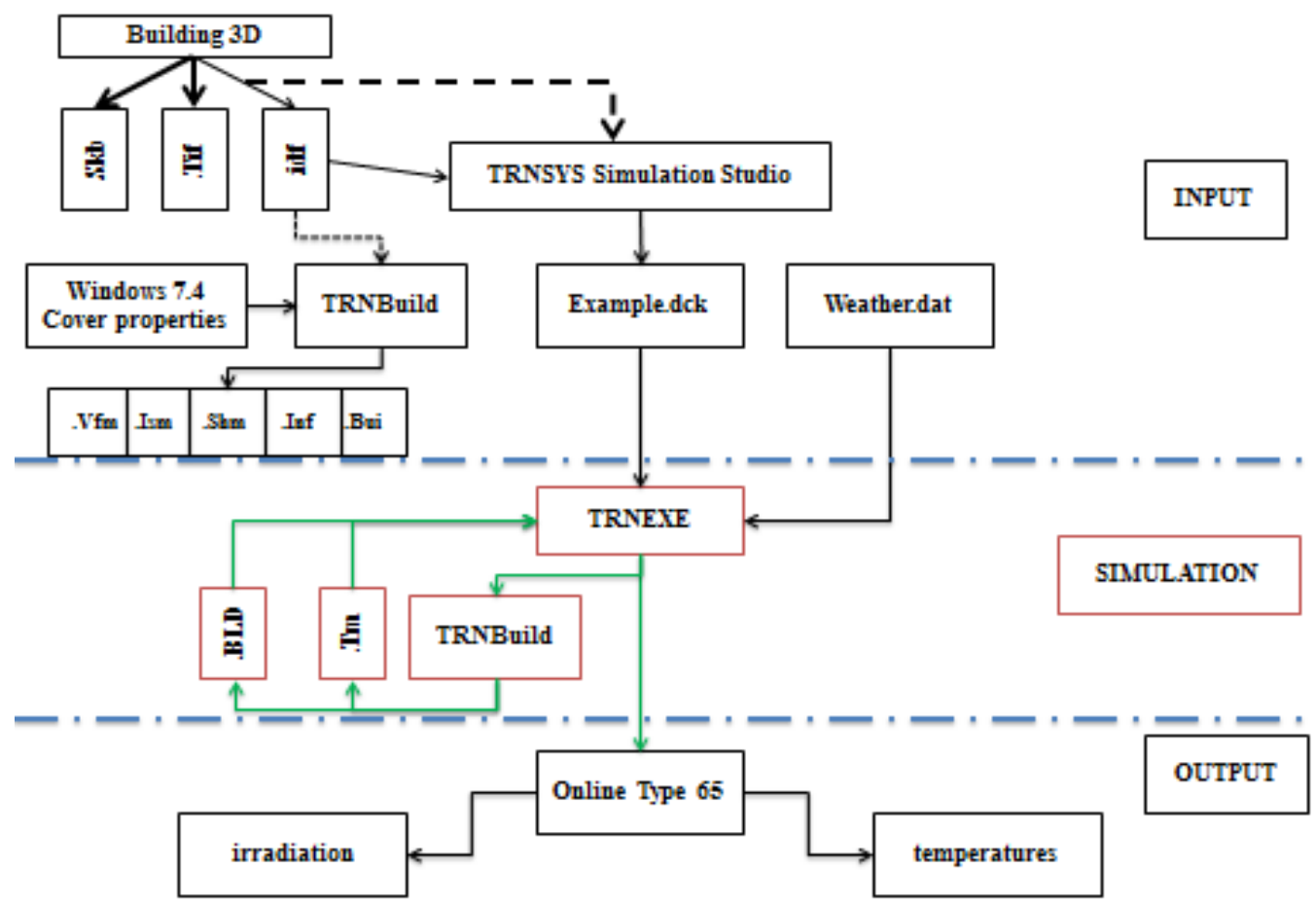

Figure 3- Diagram of dynamic building simulation in TRNSYS

In the present survey, the greenhouse was classified into two zones: above and below the surface ground for simulation purposes, section below is consisting of H-0-0, S- 0-140, W-90-90, N-180-90, N-180-140, N-180-40, E-27090, E-290-45 walls that constructed by soil where the walls of S-0-20, E-290-90, W-110-70 and W-75-60 covered by polyethylene film. Cover thickness was $0.2 \mathrm{~mm}$ and convection heat transfer coefficient was $2.44 \mathrm{~W} \mathrm{~m}^{-2} \mathrm{~K}^{-1}$. All surfaces (walls, floor, and roof) of greenhouse is defined in Table 1. The software window 7 (Berkeley lab, CA) was used to calculate transmittance properties of the cover (TRNSYS 17 Manual, 2017).

Journal of Agricultural Sciences (Tarım Bilimleri Dergisi) 26 (2020) 488-498 
Table 1- Specification of different surfaces of modeled greenhouse

\begin{tabular}{lrrrr}
\hline Surface & Type & Area $\left(\mathrm{m}^{2}\right)$ & Category & Condition \\
\hline 1 & Ground floor & 87.60 & Boundary & H-0-0 \\
2 & Soil wall & 22.87 & Boundary & S-0-140 \\
3 & Soil wall & 5.81 & Boundary & W-90-90 \\
4 & Soil wall & 19.00 & Boundary & N-180-90 \\
5 & Soil wall & 46.83 & Boundary & N-180-140 \\
6 & Soil wall & 18.00 & Boundary & N-180-40 \\
7 & Soil wall & 5.67 & Boundary & E-270-90 \\
8 & Soil wall & 9.33 & Boundary & E-290-45 \\
9 & Poly ethylene & 121.68 & External & S-0-20 \\
10 & Poly ethylene & 5.44 & External & E-290-90 \\
11 & Poly ethylene & 2.00 & External & W-110-70 \\
12 & Poly ethylene & 10.80 & External & W-75-60 \\
\hline
\end{tabular}

To simulation the thermal behavior, TYPE56 requires a several building data like geometrical data, wall construction data and some other data which influence the building such as radiation, ambient temperature, humidity, and building schedules. At first, the data were collected and then defined for the TRNSYS simulation. Figure 2 shows a schematic flow diagram of present thermal building simulation with TRNSYS.

\subsection{Construction of passive solar greenhouse}

To assessment and validation of simulated model, a solar greenhouse was built for cold climate (Figure 4a). All the used bars were woody because of its thermal insulation property. The greenhouse structure had well-insulated by soil walls and a floor $6.00 * 17.40 \mathrm{~m}^{2}$ and glazing on the south wall climate (Figure $4 \mathrm{~b}$ ).

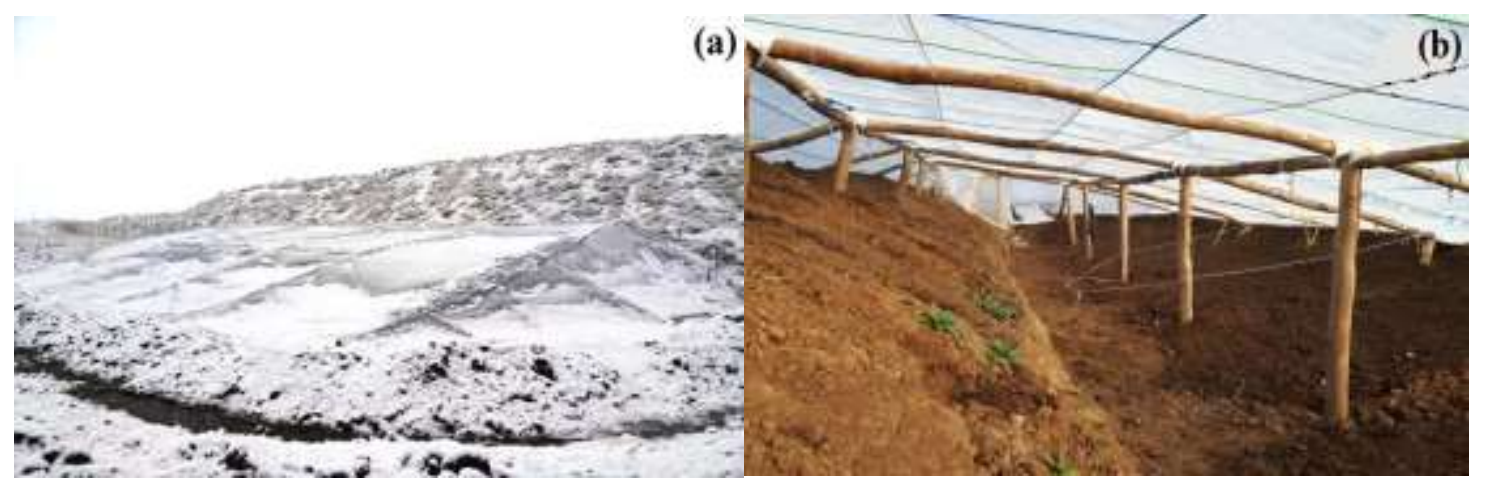

Figure 4- Outside (a) and inside (b) of greenhouse in winter

The north wall was created by the excavated soil of floor while in the passive solar greenhouse in last research was built by light weight concrete block, heavy weight concrete, wood, and common brick (Figure 4b).

The north wall size contained three parts of 5.11, 18.00, 46.86, and $19.00 \mathrm{~m}^{2}$ (sum $88.97 \mathrm{~m}^{2}$ ) which $18 \mathrm{~m}^{2}$ of them was placed below ground surface. The bottom part of the south, west, and east wall were sloping and constructed below ground surface. The overall roof area of each three sides (south, east and west) was $168.48 \mathrm{~m}^{2}$. Also, the area under cultivation was $168.55 \mathrm{~m}^{2}$ that was consisted of ground floor and the bottom part of the south, west, and east. The highest indoor point of the greenhouse was $3.20 \mathrm{~m}$ at the center of greenhouse floor (Figure 4b).

Thermal conductivity coefficient and thermal resistance of employed polyethylene were $0.4796 \mathrm{~W} \mathrm{~m}^{-1} \mathrm{~K}^{-1}$ and 0.41 $\mathrm{m}^{2} \mathrm{~K} \mathrm{~W}^{-1}$, respectively. The door and ventilation flaps have been installed on the front corners of the greenhouse in east and west side (Figure $4 \mathrm{a}, \mathrm{b}$ ). 


\section{Results and Discussion}

The indoor air temperature and solar radiation data was obtained by TRNSYS simulation from 1 January till 1 March (1440 hours). Prediction model was created using the average air temperature and solar radiation (of snowy, rainy, cloudy, and sunny days) collected by TRNSYS. To validate TRNSYS model, these data were subsequently compared with the measured average temperature in snowy, rainy, cloudy, and sunny days (Figure 5).

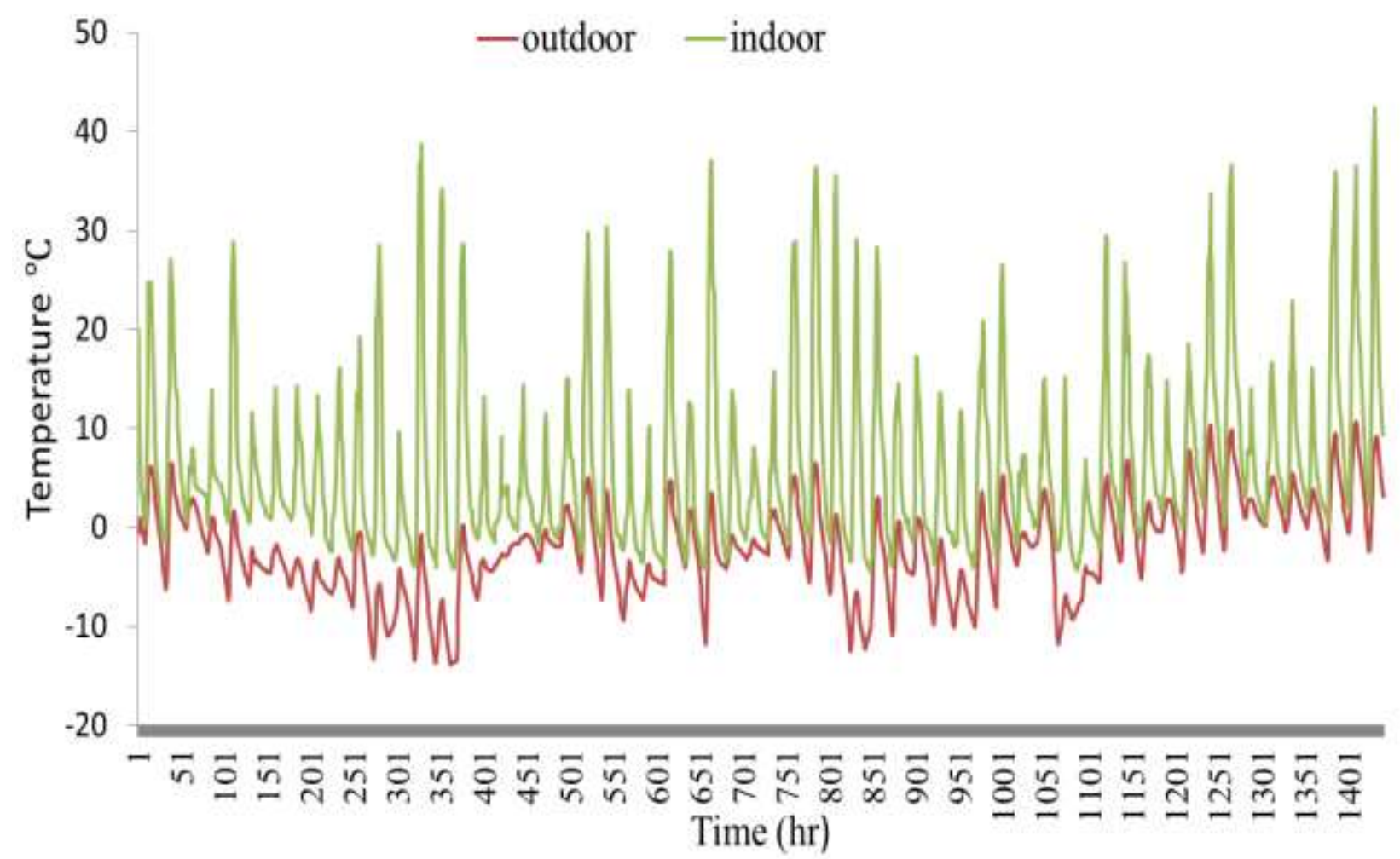

Figure 5- The outdoor (red line) and indoor (green line) temperatures in simulation studio of TRNSYS software

\subsection{Modeling results greenhouse during January and February months}

The results of modeled greenhouse air temperatures and TISR are well investigated from 1 January to 1 March (1440 hours). The indoor air temperature (green line) and the outdoor air temperature (red line) showed in Figure 5. The results presented in this figure show that the greenhouse air temperature varied from -4.3 to $32.40{ }^{\circ} \mathrm{C}$ while the outdoor temperature fluctuated between -13.8 to $10.6{ }^{\circ} \mathrm{C}$. More specifically, minimum indoor temperature was recorded on freeze day (4 February), but the lowest outdoor temperature occurred on 15 January $\left(-13.8^{\circ} \mathrm{C}\right)$. In a research conducted by Beshada et al (2006) who used thermal blanket to cover greenhouse at night, the results obtained showed that in the coldest day in February, lowest recorded nighttime temperature in the inside greenhouse was $-4.9{ }^{\circ} \mathrm{C}$ while the outdoor greenhouse temperature was $-29.2^{\circ} \mathrm{C}$. In another study, Wei et al (2017) who used solar water heating method using solar energy in a water storage tank for heating the greenhouse during the night. In this system, the air temperature greenhouse increased $3.7^{\circ} \mathrm{C}$ at night. The inside-outside temperature different ranged from 14.3 to $21^{\circ} \mathrm{C}$ (Bashada et al 2006; Wei et al 2017).

Also, results of solar radiation on walls showed a variation of 190 to $3811 \mathrm{~kJ} \mathrm{~h}^{-1} \mathrm{~m}^{-2}$ in TISR values in the coldest days during January and February months. In snow day, TISR were between 190 and $760 \mathrm{~kJ} \mathrm{~h}^{-1} \mathrm{~m}^{-2}$. In better word, the TISR values obtained were 623.231, 480.273, 567.521, and 278.058 MJ for south, floor, east, and west walls in January and February months, respectively (Figure 6). 


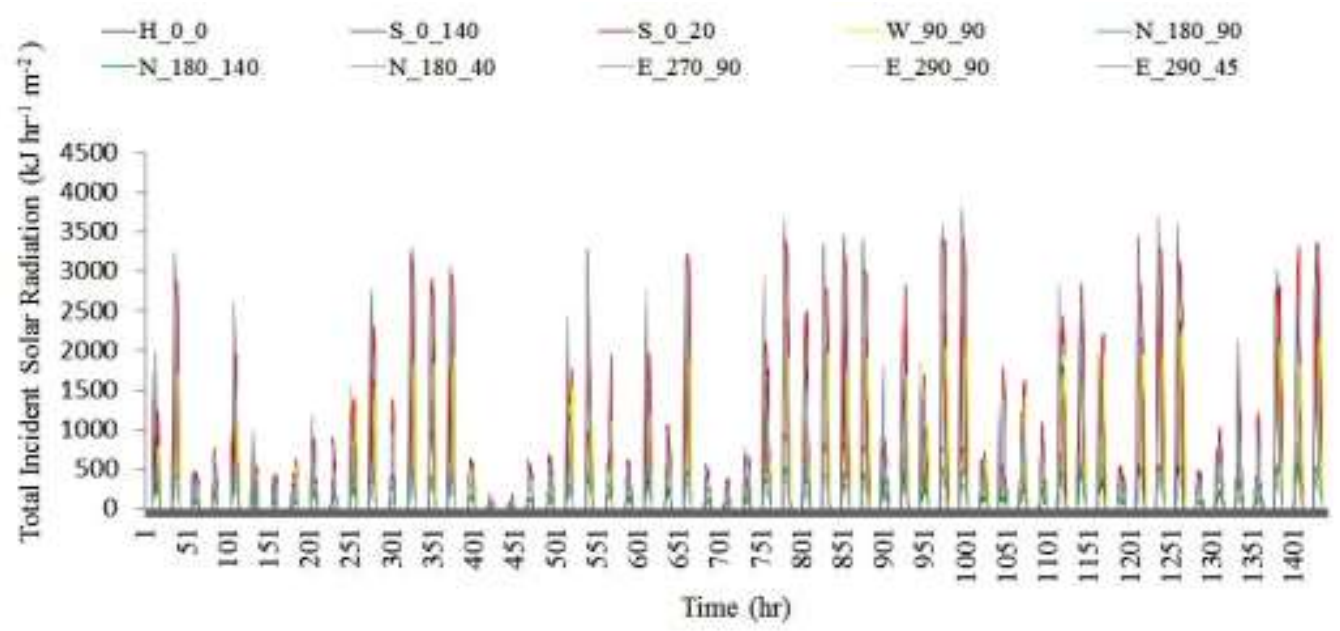

Figure 6- Total incident solar radiation on walls for 1440 hours from 1 January to 1 March

Temperature levels measured at different points in the greenhouse showed that the minimum and maximum temperatures were observed around the vicinity of the northern wall which was $9 \pm 1$ and $15 \pm 1{ }^{\circ} \mathrm{C}$ higher than the outdoor air temperature (Figure 7). The maximum temperature recorded in N, I, M, and H points in snowy, cloudy, and rainy days (Figure 7). In the study of Bin et al (2016) report their greenhouse could maintain indoor temperature above $8.2{ }^{\circ} \mathrm{C}$ by removable back walls when minimum of temperature in polyethylene greenhouse was $2.9^{\circ} \mathrm{C}$. The maximum difference of indoor and outdoor in single span greenhouses was $9{ }^{\circ} \mathrm{C}$ whereas the systems of half- removable back wall and fully- removable back wall was 6.8 and $6.1{ }^{\circ} \mathrm{C}$, respectively. Recently, Jieyu et al (2017) built a greenhouse including north wall which could storage heat energy during day. They employed this saved energy using fans for heating the greenhouse during the nights. However, the air temperature in greenhouse ranged from 1.18 to $12.56{ }^{\circ} \mathrm{C}$ while whiteout storage heat ranged from -3.9 to $12.56{ }^{\circ} \mathrm{C}$ (Bin et al 2016; Jieyu et al 2017). In the present study, indoor and outdoor temperatures of the greenhouse were below zero for 168 and 982 hours, respectively.

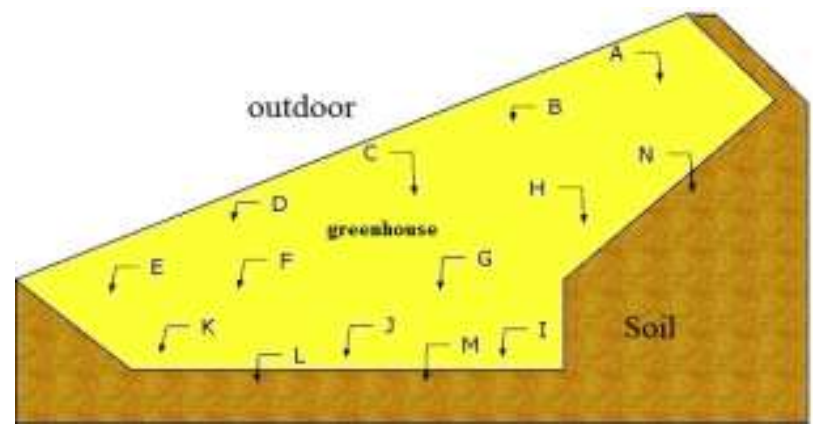

Figure 7- Points defined for measuring of temperature in greenhouse

For more examination of the solar radiation effects on the greenhouse walls, the TISR value were recorded during four different days with different amounts of solar radiation (Figure 8). In terms of climate condition, during snow days, south wall (S-0-20) showed highest TISR (1630 kJ hr-1 $\mathrm{m}^{-2}$ ) between 9:30 and 16:45. At the same time, results of present TRNSYS model showed that the maximum air temperature was $15.15{ }^{\circ} \mathrm{C}$ at $16: 00$. While outdoor air temperature showed $6.95{ }^{\circ} \mathrm{C}$ reduction (Figure 8a), while on sunny day (31 January) the inside air temperatures showed a high increment. Although solar radiation was increased by air temperature increasing, however, as expected solar radiation extremely decreased after 16:00. The largest indoor-outdoor air temperature difference was recorded by 28.84 ${ }^{\circ} \mathrm{C}$ at 15:30. Also, amount of TISR at concurrent air temperature was $2974 \mathrm{~kJ} \mathrm{hr}^{-1} \mathrm{~m}^{-2}$ which was observed in the east wall (Figure 8b). The results of air temperature at cloudy air condition are shown in Figure $8 \mathrm{c}$ which reveal a constant temperature during four hours from 12:30 to 16:30. In addition, the maximum TISR in cloudy day was highly decreased by $1057 \mathrm{~kJ} \mathrm{hr}^{-1} \mathrm{~m}^{-2}$ which was recorded on south wall. Overall, the minimum TISR values were observed in cloudy and 
rainy days and on the top of that these days had the lowest observed different radiation and temperature between all the days (Figure 8c, d).
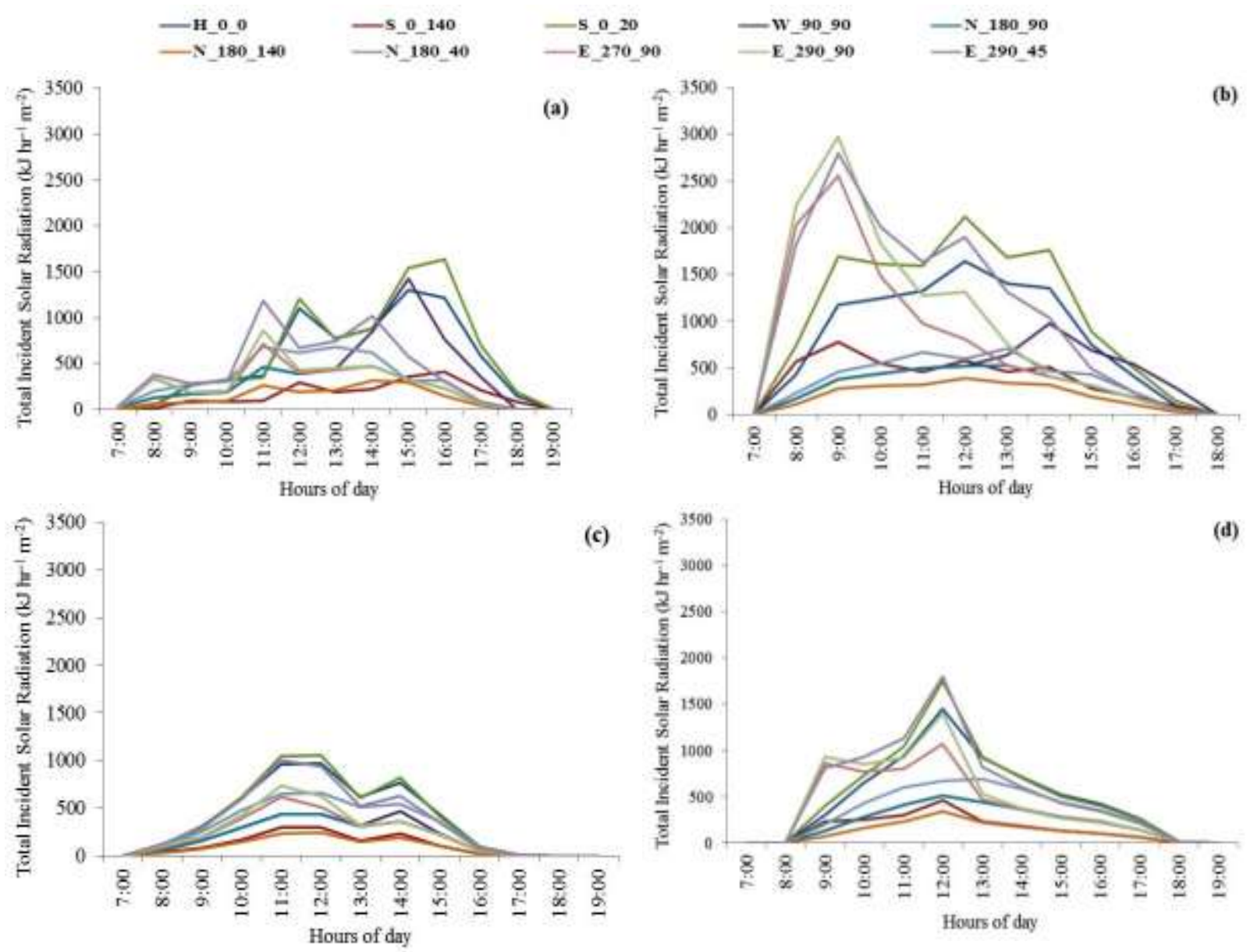

Figure 8- TISR at air condition of: (a) snow day, (b) sunny day, (c) cloudy day, and (d) rainy day

In regarding to investigate heating greenhouse during cold climate, Candy et al (2012) investigated on a solar greenhouse and their findings showed that the lowest temperature was around 2 to $3{ }^{\circ} \mathrm{C}$ which was happened at 7:00 am. More specifically, the average air temperature of indoor greenhouse was $3.5^{\circ} \mathrm{C}$ between sunset and sunrise, which indicated on this fact that their greenhouse could led to a $1.2{ }^{\circ} \mathrm{C}$ higher air temperature than the average outdoor. During daytimes, the average air temperature inside the greenhouse was $14.3{ }^{\circ} \mathrm{C}$ while the average outdoor was $7.4{ }^{\circ} \mathrm{C}(\mathrm{Candy}$ et al 2012). In another research, Zhang et al (2015) investigated on greenhouse heating during cold climate and their results showed that the maximum temperature was monitored in the floor greenhouse in cloudy day and maximum temperature was recorded in the greenhouse ceiling in sunny day. The indoor air temperature varied from -5 to $10{ }^{\circ} \mathrm{C}$ while outdoor air temperatures were -4 to $29.2^{\circ} \mathrm{C}$. In addition, they reported that the average indoor-outdoor air temperature difference during nights were 2.4 and $-13.1^{\circ} \mathrm{C}$ (Zhang et al 2015).

\subsection{Validation}

Figure 9 shows average temperatures measured and modeled in different conditions such as snow, cloudy, rainy, and sunny days. Results between average measured temperature and modeled data displayed that minimum measured temperature in snowy day was $-2.2{ }^{\circ} \mathrm{C}$ while minimum modeled data was $-4.39{ }^{\circ} \mathrm{C}$ and average maximum measured temperature and modeled data were $+15{ }^{\circ} \mathrm{C}$ at $16: 00$, while the difference between the measured and modeled data in snowy, rainy, and sunny days were $0.2,0.3$, and $0.2^{\circ} \mathrm{C}$, respectively (Figure 9 ). 

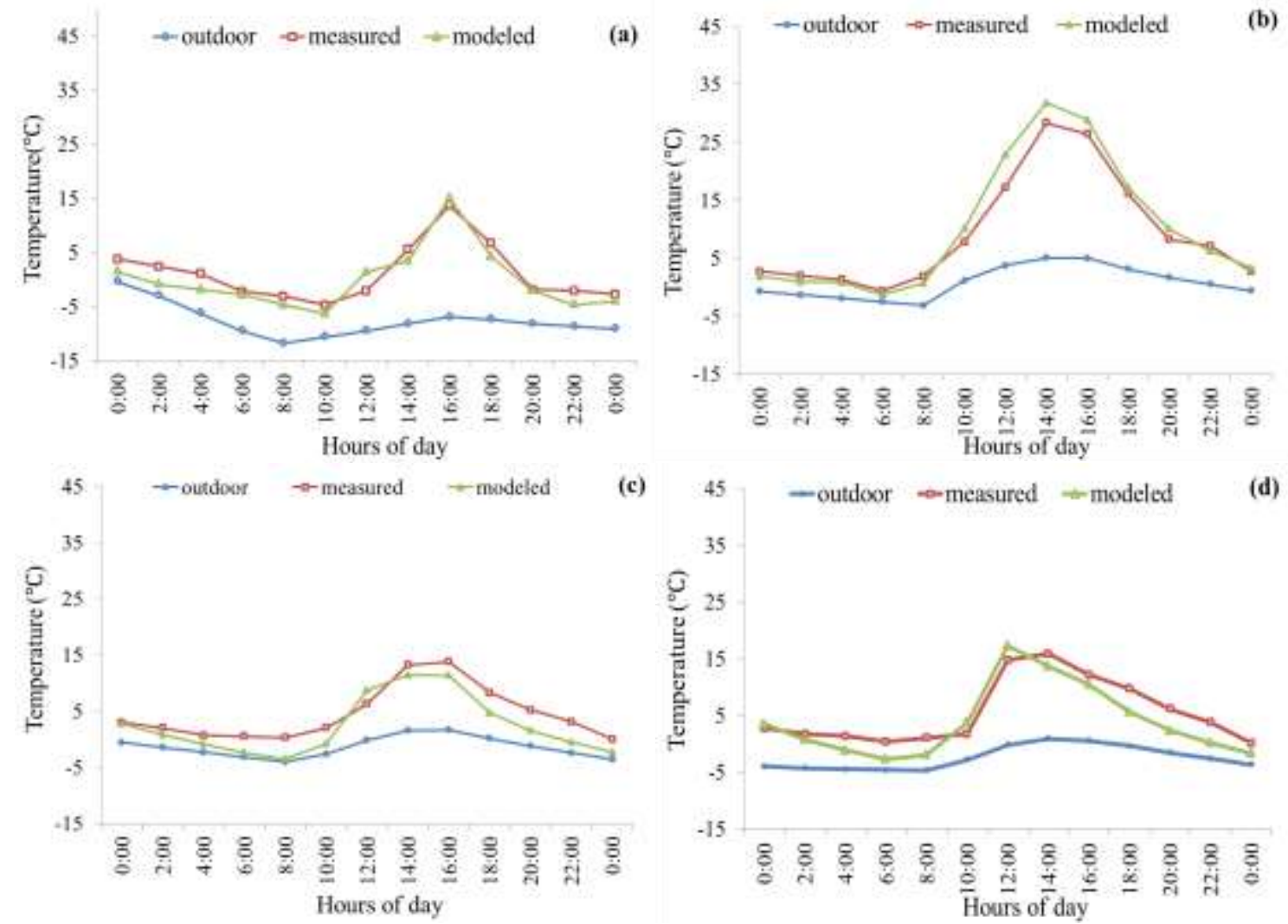

Figure 9- Average air temperature for modeled and experimental data at air condition of: snowy (a), sunny (b), cloudy (c), and rainy (d) day

Analysis of regression is shown in Figure 10. Results showed a significant linear regression between the values of measured and simulated model. The coefficient of determination $\left(\mathrm{R}^{2}\right)$ indicated $95.95 \%$ between values obtained from measured and modeled data.

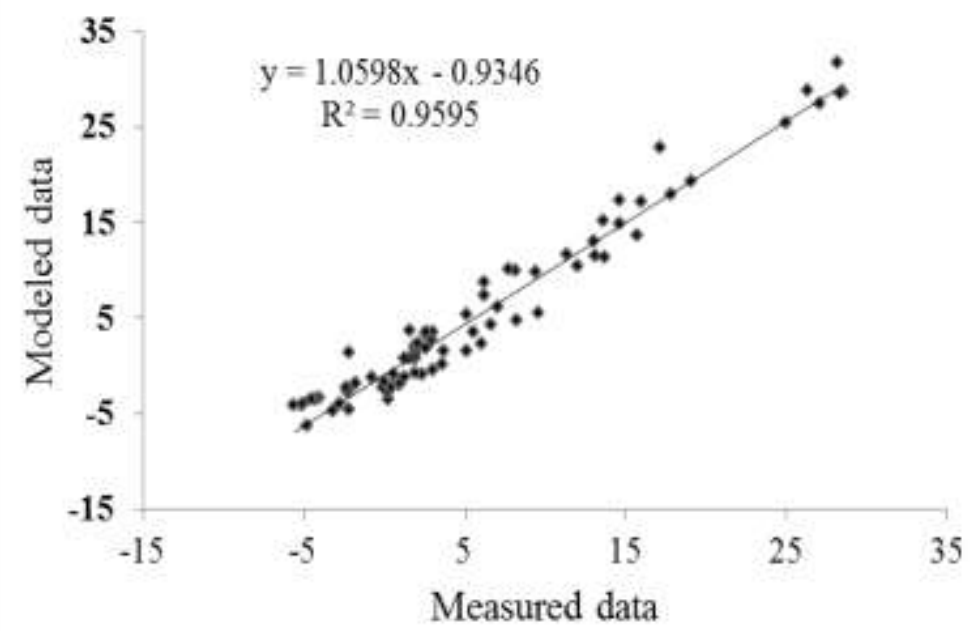

Figure 10- Relationship between measured and modeled data for indoor temperature of greenhouse 


\section{Conclusions}

In this work, a passive solar greenhouse was built in depth $1 \mathrm{~m}$ underground and analyzed based on two parameters of outdoor-indoor air temperature and TISR values during two cold months (January and February) and also a TRNSYS model was built to optimize greenhouse characteristics. The following conclusions could be derived based on the findings obtained in the present study:

- In modeled passive solar greenhouse, north wall was built vertical rather than Radiation line and made by excavated soil. A part of south, north, west, and east walls is placed in $1 \mathrm{~m}$ underground that this method prevented from heat loss. The Area under cultivation was $168.55 \mathrm{~m}^{2}$ and the polyethylene cover area was $168.48 \mathrm{~m}^{2}$. In this design, TISR in the north wall was 484 MJ during January and February and there was the possibility of cultivation in it.

- Results of present TRNSYS model showed slight difference between average measured and simulation greenhouse temperatures which were up to -2 in rainy night and $2.6{ }^{\circ} \mathrm{C}$ in sunny day. This means that present TRNSYS model could predict indoor air temperature condition as well.

- Insolation of north wall and the lower part of west, east, and south walls slightly increased the indoor air temperature which could be due to the fact that the temperature was below zero for 168 hours while the outdoor air temperature was 982 hours below zero.

- The obtained coefficient of determination $\left(\mathrm{R}^{2}\right)$ was $95.95 \%$ for measured and modeled data that the present model is suitable for simulation of TISR and the indoor air temperature.

\section{References}

Alkilani M, Sopian K, Alghoul M, Sohif M \& Ruslan M (2011). Review of solar air collectors with thermal storage units. Renewable and Sustainable Energy Reviews 15: 1476-1490

Asdrubali F, Cotana F \& Messineo A (2012). On the evaluation of solar greenhouse efficiency in building simulation during the heating period. Energies 5(6): 1864-1880

Attar I, Naili N, Khalifa N, Hazami M, Lazaar M \& Farhat A (2014). Experimental study of controlling the greenhouse. Energy Conversion and Management 79: 543-553

Beshada E, Zhang Q \& Boris R (2006). Winter performance of a solar energy greenhouse in southern Manitoba. Canadian Biosystems Engineering 48(5): 1-8

Bin W, Shirong G, Jian L, Junwei W, Jian Z, Chuntao Q \& Jin S (2016). Thermal performance of single span greenhouses with removable back walls. Biosystem Engineering 141: 42-57

Candy S, Moore G \& Freere P (2012). Design and modeling of a greenhouse for a remote region in Nepal. Procedia Engineering 49: $152-160$

Carlini M, Honorati T \& Castellucci S (2012). Photovoltaic greenhouses: comparison of optical and thermal behavior for energy savings. Mathematical Problems in Engineering 2012:Article ID 743764.

Chargui R, Sammouda H \& Farhat A (2012). Geothermal heat pump in heating mode: Modeling and simulation on trnsys. International Journal of Refrigeration 35(7): 1824-1832

Chen W \& Liu W (2006). Numerical simulation of the airflow and temperature distribution in a lean-to greenhouse. Renewable Energy 31(4): 517-535

Chung M, Park J U \& Yoon H K (1998). Simulation of a central solar heating system with seasonal storage in Korea. Solar Energy 64(4-6): 163-178

Erdem C, Dewanto H, Pinar M C (2016). Renewable and sustainable energy saving strategies for greenhouse systems: A comprehensive review. Renewable and Sustainable Energy Reviews (64):34-59 
Ishigami Y, Goto E, Watanabe M, Takahashi T \& Okushima L (2014). Development of a simulation model to evaluate environmental controls in a tomato greenhouse. Acta Horticulturae 1170(35): 293-300

Jieyu L, Li L, Wang H, Konstantinos P, Minzan L \& Sigrimis N (2017). Proactive energy management of solar greenhouses with risk assessment to enhance smart specialization in china. Biosystem Engineering 158: 10-22

Joudi K A \& Farhan A A (2015). A dynamic model and an experimental study for the internal air and soil temperatures in an innovative greenhouse. Energy Conversion and Management 91(10): 76-82

Marucci A, Carlini M, Castellucci S \& Cappuccini A (2013). Energy efficiency of a greenhouse for the conservation of forestry biodiversity. Mathematical Problems in Engineering. ID 768658

Mashonjowa E, Ronsse F, Milford J R \& Pieters J G (2013). Modelling the thermal performance of a naturally ventilated greenhouse in Zimbabwe using a dynamic greenhouse climate model. Solar Energy 91: 381-393

Mathala J G \& Pitam C (2002). Effect of greenhouse design parameters on conservation of energy for greenhouse environmental control. Energy (27): 777-794

Patil R U, Atre M N, Bailey G \& Power G (2013). An integrated sustainable food production and renewable energy system with solar \& biomass chp. American Solar Energy Society

Sethi V P, Sumathy K, Chiwon L \& Pal D S (2013). Thermal modeling aspects of solar greenhouse microclimate control: a review on heating technologies. Solar Energy 96: 56-82

Taki M, Ajabshirchi Y, Ranjbar S, Rohani A \& Matloobi M (2016). Modeling and experimental validation of heat transfer and energy consumption in an innovative greenhouse structure. Information Processing in Agriculture 3: 157-174

TRNSYS 17 Manual(2017). Volume 5, Multizone Building modeling with Type56 and TRNBuild, Solar Energy Laboratory, University of Wisconsin, Madison, WI

Vadiee A \& Martin V (2012). Energy management in horticultural applications through the closed greenhouse concept, state of the art. Renewable and Sustainable Energy Reviews 16(7): 5087-5100

Vadiee A \& Martin V (2013). Energy analysis and thermoeconomic assessment of the closed greenhouse - the largest commercial solar building. Applied Energy 102: 1256-1266

Vadiee A \& Martin V (2014). Solar blind system- solar energy utilization and climate mitigation in glassed buildings. Energy Procedia 57: 2023-2032

Voulgaraki S I \& Papadakis G (2008). Simulation of a greenhouse solar heating system with seasonal storage in Greece. Acta horticulturae (801):757-764

Wei L, Zhang Y, Fang H, Xinglin K \& Qichang Y (2017). Modelling and experimental verification of the thermal performance of an active solar heat storage-release system in chinese solar greenhouse. Biosystem Engineering 160: 12-24

Zhang L P, Xu J M, Tang X, Li Z \& Shi J (2015). A low cost seasonal solar soil heat storage system for greenhouse heating: Design and pilot study. Applied Energy 156: 213-222 